\title{
Francesco Benci and the Origins of Jesuit Neo-Latin Epic
}

\author{
Paul Gwynne
}

The Quinque martyres e Societate Iesu in India (Venice: Muschius, 1591) by Francesco Benci, S.J. (1542-94), professor of rhetoric at the Collegium Romanum, is a remarkable poem for many reasons, not least because it is the first poem of a new genre: the Jesuit epic. ${ }^{1}$ The six-book poem centers upon the first Jesuit mission to India $(1580-83)$ and culminates in the journey of five Jesuits led by Rodolfo Acquaviva $\left(155^{0}-83\right)$ to the province of Salcete in the summer of 1583 ; their attempt to found a new church; their subsequent martyrdom in a local riot; and reception into paradise. ${ }^{2}$ This narrative is set within the broader context of Jesuit missions across the world, and articulated via the medium of classical epic in which the heroism of the ancient warriors is redefined in terms of the Jesuit vocation. Indeed, the honor and virtue of these new heroes is no longer derived from military achievement, but rather from a heroic Christian piety which it is the poet's intention to immortalize in epic encomium: "Non decet in tenebris longa sub nocte iacere, / Lumine quae seros accendent uisa nepotes" (These events which will inspire later followers, when seen in the light, should not lie hidden in the shadows of a long night, Quinque martyres, $5 \cdot 55^{1-52)}$.

1 Repeated publication attests to the popularity and success of Benci's poem. The Quinque martyres was first published in Venice in 1591, and a second, corrected version issued from the Vatican Press a year later. The poem was reprinted throughout the seventeenth century in Benci's collected poems and afterwards in his collected works. It was also included in the massive anthology of Jesuit epic poetry, the Parnassus Societatis Iesu printed in Frankfurt in 1654. All references are taken from the second, corrected, Roman edition of 1592. For Benci, see Renzo Negri, Dizionario biografico degli italiani, 8 o vols. (Rome: Istituto della Enciclopedia Italiana, 1960-), 8 (1966): 192-93.

2 For Acquaviva see Pietro Pirri, Dizionario biografico degli italiani, 80 vols. (Rome: Istituto della Enciclopedia Italiana, 1960-), 1 (1960): 183-84; for the Jesuits in India see Ines Županov, Missionary Tropics: The Catholic Frontier in India (16th-17th Centuries) (Ann Arbor: University of Michigan Press, 2006); Alexander Henn, Hindu-Catholic Encounters in Goa: Religion, Colonialism and Modernity (Bloomington: Indiana University Press, 2014).

(C) PAUL GWYNNE, 2016 | DOI 10.1163/9789004313354_003

This is an open access chapter distributed under the terms of the Creative Commons Attribution- 


\section{The Epic Structure of the Quinque martyres}

Virgil's (70-19 BCE) Aeneid is Benci's primary-though not exclusive-epic model. Yet, it is a reading of Virgil's Aeneid mitigated both through Christian exegesis, and the Stoic philosophy of Seneca's (4 BCC-65 CE) moral essays, Marc Antoine Muret's (1526-85) edition of which Benci had seen through the press in $1585^{3}$ Neo-Latin epic also had an effect; most importantly, Marco Girolamo Vida's (1485-1566) Christiad (probably in the edition with extensive commentary made by Bartolomeo Botta [Pavia, 1569]). ${ }^{4}$ The prize-giving events at the Collegium Romanum show that Jesuit education continued to promote the studia humanitatis. ${ }^{5}$ Editions of Homer (eighth century, BCE), Lucan (39-65), Silius Italicus (26-101), Statius (c.40/50-c.96), and Valerius Flaccus (first century CE), as well as the early Christian epicists Juvencus (fourth century CE), Sedulius (fl. 425-50), and Arator (sixth century CE), were awarded for composition in the ancient languages. ${ }^{6}$ Neo-Latin epic was also admired. The De partu Virginis by Jacopo Sannazaro (1458-1530) and Vida's Christiad were also singled out for praise:

Quid praesentia saecula

Frustra deprimimus turpiter invidi?

Est hoc nobile par virum

Quos laudent etiam pristina saecula.

3 L. Annaeus Seneca a M. Antonio Mureto correctus et notis illustratus (Rome: Bartholomaeus Grassius, 1585).

4 See Paul Gwynne, "Epic," in Readings in Neo-Latin Literature, ed. Victoria Moul (Cambridge: Cambridge University Press, 2015).

5 However, "it is certainly worth reminding ourselves that the supreme telos of Jesuit education was not the production of impressive or sensitive scholars of the classical language or cultures, but of pious and persuasive champions of the Catholic Church." Yasmin A. Haskell, Loyola's Bees: Ideology and Industry in Jesuit Latin Didactic Poetry (Oxford: British Academy at the Oxford University Press, 2003), 9.

6 The prize-giving was held after performances of Benci's plays Ergastus (October 30, 1587) and Philotimus (December 29, 1589); see Francesco Benci, Carminum libri quattuor eiusdem Ergastus et Philotus dramata (Ingolstadt: David Sartorius, 1592), 250-56; 318-24. By the late seventeenth century, however, tastes in literature had changed. Ranieri Carsughi (1647-1709), lecturer at the Collegium Romanum, advised his students to resist the temptations of Lucan, Statius, and Claudian, and look only to Virgil when writing epic verse. See Yasmin A. Haskell, "Practicing What They Preach? Vergil and the Jesuits," in A Companion to Vergil's Aeneid and Its Tradition, ed. Joseph Farrell and Michael C.J. Putnam (Oxford: Wiley Blackwell, 2010), 203-16; 203; also Haskell, Loyola's Bees, 258-68. 
(Why do we enviously denigrate our own times? The men of our own age, whom the ancients would praise, are equally fine. $)^{7}$

Benci's poem references this entire epic canon, both ancient and modern. Indeed, the six-book structure deliberately echoes Vida's Christiad; yet, it is ${ }^{8}$ Aeneas's divinely ordained journey to found Rome which provides the key point of reference for the dramatic account of the mission to Salcete. The opening lines of the proem resonate with references to the Aeneid while at the same time contrasting the classical world with the Christian:

Felices sociorum obitus, qui littore in Indo, Finitimam qua Goa uetus Salsethida tangit, Christum animis pulchroque olim per vulnera fuso Sanguine testati, laetis meruere piorum

5 Adscribi ordinibus, sit fas mihi munere uestro

Dicere caelicolae; vos o memorate canenti,

Quae mens, qui sensus fuerit morientibus, et quae

Gloria tanti operis sublimes aethere tollat.

Vicerunt illi uobis spectantibus: illis

10 Ante oculos interque manus data munera uestras:

Cum Deus aeternum stent ut sua praemia laudi,

Aurea uictrici uelauit tempora fronde,

Et dedit emeritis pretium uictoribus ingens

Ferre mano aurifera decerptam ex arbore palmam.

15 Ad nos tam longo tractu terraeque marisque

Tam celebris facti vix nuntia peruenit aura:

Tamque procul semota oculis transmittere mente

Vix datur, et causas gestarum exponere rerum.

Vos clarum in tenebris tantis praetendite lumen.

BENCI, Quinque martyres, 1.1-19

(The blessed martyrdoms of those companions, who, upon the shores of India where ancient Goa joins neighboring Salcete, some time ago bore witness to Christ by their courage and by their noble bloodshed, have deserved

7 Benci, Carminum libri quattuor, 254. The verse form is Asclepiadean II, consisting of one Glyconic and one Lesser Asclepiadic found in Hor. Carm. I.3, 13, 19, 36; III.9, 15, 19, 24, 25, 28; IV.1, 3 .

8 It should be noted that Benci encouraged his students to compare and contrast ancient and contemporary Rome in rhetorical debate. Three of these student orations on the old and new city were published among his Orationes et carmina (Ingolstadt: David Sartorius, 1592). 
to be inscribed among the happy ranks of the pious, if I may be permitted to sing with your gift, you who dwell in heaven. Recall for the poet their resolution, what emotions they felt as they were dying, and how the glory of their great enterprise now raises this exalted band to heaven. As you looked down, those illustrious men were triumphant, their rewards were given before your eyes and in your midst: when God wreathed their golden temples with a victorious garland so that their trophies may stand eternal in glory, and he gave to those deserving victors the great reward of holding a palm plucked from the golden tree. The wind bringing news of such a famous deed has only just reached us from distant lands and seas. One can scarcely imagine such remote events or set forth the occasion of their achievements. Spread forth your clear light in such darkness.)

In line 1, Socius is the regular word used by Aeneas when addressing his companions (e.g., Aen. 1.198), and littore in Indo (the shores of India) recalls Aeneas's arrival on "the shores of Lavinium" (Lavinia litora, Aen. 1.3). However, the felices obitus (blessed martyrdoms) of the Jesuit brothers contrasts with the difficilis obitus (difficult death) of Dido (Aen. 4.694); the word obitus is used uniquely of Dido; while the adjective felices, used only twice throughout the Aeneid, recalls the felices animae (blessed spirits) sought by the Sibyl and Aeneas in the Underworld (Aen. 6.669-70). These are relatively small points, but they are not minor. They confirm that Benci was consciously using his Virgilian model, and that we ought to expect more evidence in the rest of the poem. Yet, at line 5, Benci does not appeal to the Muses of antiquity for inspiration but rather to "those who dwell in heaven" (caelicolae), thus subsuming a Christian message within the epic structure. ${ }^{9}$ Moreover, Benci's poem is intended not merely to narrate the martyrs' story in heroic episodes and images but also to evoke the emotions and feelings (sensus) they experienced throughout their dangerous mission. His aim was to provide inspiration for the burgeoning group of Jesuit scholastics being trained to pursue equally dangerous enterprises. An address to the readership, and more specifically to students at the Collegium Romanum, equates the Jesuit missionaries with the wandering heroes of epic and, like Aeneas's frequent addresses to his companions, is intended to bolster their fortitude and resolve:

20 At vos, o socii, quibus almi nomen Iesu

Et nova praefixit pietas, et fervidus ardor, Ignati patris exemplo: quos sancta secutos Signa, per ignotas divinae lumina legis

Ferre iuvat terras: longinqua per aequora uectos

9 Cf. "Sing heavenly Muse," John Milton, Paradise Lost, 1.6. 
25 Seu procul Ammerice, seu uos diuersa Sinarum

Ora tenet, quacumque plaga vos dividit orbis

Extremus, vitae incertos, certosque pericli:

Quae vos cumque agitant curae, quae munera, quisquis

Vos labor exercet, fructu minuente laborem:

30 Si vacat, et tenuem vatis non spernitis orsum,

Accipite haec, vestras acuant quae carmina mentes,

Instillentque acres perfuso melle liquores.

Nam simul insinuans nostrorum cognita uirtus

Affectos tacita alliciet dulcedine sensus;

35 Perque obitus similes caelum sperare iuuabit.

Vestra quidem nequicquam alto non spectat Olympo

Vota Deus, magnosque animos cupientibus addit.

BENCI, Quinque martyres, 1.20-37

(But you, my companions, upon whom sweet Jesus's name and a new piety and a burning love has been fastened by Father Ignatius's example; this assists you when you have followed the holy standards to bring the light of divine law through unknown lands; borne across far oceans, whether distant America or the foreign shores of China detain you, wherever seas and far-flung lands send you, fearing for your life, and into certain danger; whatever cares oppress you, whatever tasks, whatever duty harasses you, the rewards lessen your hard work; if you have leisure, and you do not despise the meagre undertaking of the poet, then take these verses to sharpen your resolution and instill courageous draughts with their honey coating. For our brother's valor, acknowledged and affecting you at the same time, will elicit emotions influenced by a hidden sweetness, and will encourage you to hope for heaven by means of a similar death. Indeed, God in lofty heaven does not regard your prayers in vain, but gives great courage to those who long for it.)

After this exordium, the narrative starts in medias res (in the midst of events). Rodolfo Acquaviva has already spent three years at the court of the Mughal emperor Julāl-ud-Dīn Muhammad Akbar (1542-1605), trying, in vain, to procure his conversion to Christianity. ${ }^{10}$ An advocate for religious tolerance, Akbar

10 Their meetings are depicted in an exquisite miniature, illustrating a deluxe copy of the Akbarnāma [The history of Akbar] written by Abu'l Fazl ibn Mubarak (1551-1602), which is believed to have belonged to Akbar himself (Chester Beatty Library, Dublin, Ms 03.263b). For a discussion of this popular image, see Amina Okada, "The Representation of Jesuit Missionaries in Mughal Painting," in Goa and the Great Mughal, ed. Nuno Vassallo e Silva 
was interested in the religion professed by the Europeans on the coast and so invited the Portuguese to send representatives from Goa to debate their Christian beliefs with Muslim doctors at the weekly discussions held in the "Ibādat-khāna" [Hall of worship] at his court in Fatehpur Sikri. Antonio Monserrate kept a detailed account of the weekly meetings that he attended with Acquavuva. ${ }^{11}$ Realizing the impossibility of his task, Acquaviva has returned reluctantly to Goa. News of the recent execution of the Jesuit Edmund Campion (1540-81) in London adds further to his feeling of dejection and misery. ${ }^{12}$ While meditating upon these events, Acquaviva is visited by his guardian angel who transports him into the heavens in order to witness a glorious cavalcade of Christian martyrs. Christ, invoked as the rex gloriosus martyrum (the glorious king of martyrs), heads the procession. Through his example, passage into heaven is assured: "For all these people the love of Christ and a great desire for Heaven extinguish their fear of death and the bitter pain, while they are scorning their wounds and pressing on with their great undertaking," the guardian angel observes. ${ }^{13}$ Just as Vida in the Christiad had imagined Christ's procession to Calvary in terms of a victorious Roman general's triumph to the capitol (Christiad, 5.420-47), so here the martyrs' magnificent parade is seen as a celebration:

425 Sed nec cuncta licet paucis percurrere, nec sunt

Omnia clara procul spectantibus; aspice summa

Ora virum, densosque humeros, huc dirige gressum,

Victricem aspicies diverso funere gentem.

Pars rapido submersa mari, pars stipite fixa,

and Jorge Flores (London: Scala, 2004), 190-99; also Gian Carlo Calza, ed., Akbar: The Great Emperor of India (Milan: Skira, 2012), 73; and Jorge Flores, Mughal Padshah: A Jesuit Treatise on Emperor Jahangir's Court and Household (Leiden: Brill, 2015), and more generally, Jeremiah P. Losty and Malini Roy, Mughal India: Art, Culture and Empire (London: British Library, 2012), 26-79.

The Commentary of Father Monserrate, S.J., on his Journey to the Court of Akbar, trans. by J.S. Hoyland with annotations by S.N. Banerjee, (New Delhi: J. Jetley for AES services, reprint. 1992; original edition 1922); also A. Azfar Moin, The Millennial Sovereign. Sacred Kingship and Sainthood in Islam (New York: Columbia University Press, 2012), 146-9.

12 For Campion, see Thompson Cooper, Oxford Dictionary of National Biography: From the Earliest Times to the Year 2000 (oDNB), ed. H.C.G. Matthew and Brian Harrison, 61 vols.

(Oxford: Oxford University Press, 2004), 3:850-54.

13 Omnibus his mortisque metum, crudique doloris,

Vulnera dum spernunt, et coeptis grandibus instant, 465 Christi extinguit amor, caelique immensa cupido.

BENCI, Quinque martyres, 1.463-65 
430 Pars pice, pars oleo, liquentis et unguine cerae Perfusa, admotis facibus, lamnisque perusta, Aurea cum volucri penetravit ad astra favilla. BENCI, Quinque martyres, 1.425-32

(Yet it is neither appropriate to race through all this in a few words, nor is everything clear to the spectators at a distance. Look at the men's proud expressions and the dense line, turn your attention here and you will see a people victorious in the diverse manner of their deaths. Some were drowned in the fast-flowing sea, some crucified, some covered in pitch, some in oil, or the grease of melting wax, then ignited with torches or scorched with red-hot sheets of metal; with their flickering ashes, they have gained entrance to golden heaven.)

The pageant culminates in the vision of the English martyr Edmund Campion and his companions Alexander Briant (1556-81) and Ralph Sherwin (1550-81), who had recently been brutally executed at Tyburn (December 1, 1581) and whose deaths are thus ennobled and universalized through the precedent of the early Christian saints. ${ }^{14}$ Indeed, their example leads Acquaviva to exclaim: "O new examples of ancient virtue, which future ages will soon admire! O blessed piety! $O$ the brave hearts of these brothers, whom Christ has deemed worthy with such a great honor!"15 According to contemporary sources, when news of Campion's death reached Goa, Acquaviva was observed lamenting that he had not yet been given a similar opportunity for martyrdom. Book 1 closes with Acquaviva's resolve to embrace a similar fate. ${ }^{16}$

The first half of book 2 comprises a dialogue between Rodolfo Acquaviva and João Vicente da Fonseca, archbishop of Goa (1582-87) on the forthcoming Jesuit mission and introduces Acquaviva's companions: the Spaniard Afonso Pacheco (c.1551-1583), the Italian Pietro Berno da Ascona (1553-83), and two

14 For Briant, see ODN B, 2:1217-18; for Sherwin, see ibid., 50:343.

15 Hosne igitur, meus Edmundus, fortisque Briantus,

Seruinusque, ducesque alii, duxere triumphos?

Excipit exultans Aquiuiuius. O noua priscae

Virtutis, ueniens quae olim mirabitur aetas,

Exempla! O felix pietas! O fortia fratrum

Pectora, quos Christus tanto est dignatus honore!

BENCI, Quinque martyres, 1.579-84

16 The Commentary of Father Monserrate, sJ, on His Journey to the Court of Akbar, trans.

J.S. Hoyland with annotations by S.N. Banerjee (New Delhi: J. Jetley for AEs services, reprint. 1992; original edition 1922). The new and revised annotated edition of this work is forthcoming from the Institute of Jesuit Sources at Boston College. 
Portuguese, Francisco António (d.1583) and Francisco Aranha (1551-83). ${ }^{17}$ Berno had already been working in the area and had personally destroyed many images:

265 "An illuc Ibitur," exclamat laetanti pectore Bernus,

"Nos ubi (pro miseri, quis tantus mentibus error!)."

Mutorum delubra palam, simulacraque diuum

Fregimus, et fumo inuisas inuoluimus aras,

270 Et circum iniecto late populauimus igni?

Qui etiam, immanem candenti corpore uaccam,

Cui (scelus) effusis precibus sacrisque litabant,

Strauimus, et caeso uellentes uiscera uentre,

In labrum solido positum de marmore, templi

275 Pro foribus, quo se facturi sacra lauabant,

Mersimus, et sanie fontes turbauimus atra.

BENCI, Quinque Martyres, 2. 265-76.

("Are we going to that place (on behalf of those wretches, whose minds are enmeshed in such great error!)," exclaims Berno with his heart racing, "where we smashed the shrines and images of the mute gods in broad daylight, and enveloped the hated altars in smoke, and laid everything round and about to waste with firebrands? We even knocked to the ground a huge white cow, to which (wicked!) they were making sacrifice with excessive prayers and sacred rites; we ripped open its stomach, tore out its entrails and threw them into the marble pool before the temple doors, where they were usually washed themselves before attending their sacred rites, and we made those fountains foul with black gore.")

Hindu ritual here is equated with pagan sacrifice (compare Dido at the altars, Aen. 4.56-64); moreover, intertextual references in the previous lines associate Berno's actions with the aged boxer Entellus (Aen. 5.394-484); Berno's destruction of the sacred cow is thus paralleled with Entellus's sacrifice of a great white ox to Hercules, thereby associating these Jesuit missionaries with victorious classical athletes.

In book 3, the brothers assemble and Afonso Pacheco describes previous missions and the problems encountered. If book 1 offers a glimpse of paradise, then the journey to Salcete in book 3 is a classical katabasis (descent). The crossing is described in language that echoes Aeneas's descent into the Underworld; for

17 The Metropolitan See of Goa, known as "the Rome of Asia," had jurisdiction from the Cape of Good Hope across South and East Asia. 
example, the brothers' ferryman recalls Charon, while the description of Hindu rites and practices (perhaps the ancient cobra festival Nag Panchami?) evokes the monsters assembled at the entrance to the Underworld. This association continues into book 4, where Acquaviva offers an account of the religious debates at the court of Akbar. ${ }^{18} \mathrm{He}$ dramatically presents Christ to the Mughal emperor: Hic vir, hic est (This is the man, here he is; Benci, Quinque martyres, 4.317); these are the words Virgil used to introduce Emperor Augustus at the conclusion of the parade of future Roman heroes (Aen. 6.792). The bold quotation suggests that Virgil was wrong and that Christ's empire surpasses the temporal empire of Augustus (and by association, that of Akbar). The explanation of the Christian message affords Benci an opportunity for an epyllion on the life of Christ in the tradition of Sannazaro and Vida. A break in the narrative between Christ's ministry and his passion and a direct quotation from Virgil: maius opus moveo (I set in motion a greater work; Aen. 7.45) marks the second half of the poem in which Christ's passion will prefigure Acquaviva's own inevitable martyrdom. Book 4 concludes with Pentecost. As the apostles disperse, particular emphasis is given to Thomas's mission into India.

The premonitions of martyrdom, revealed to Acquaviva in the prophetic visions of book 1, are realized in book 5 when the local population attacks. In a divine council, Christ, Ignatius, and Xavier approve their imminent deaths:

725 Omnibus his decus eximium; mens omnibus una, Omnes laetifico declarant gaudia vultu Cum Deus ostendit socios sancire profuso Sanguine, quam sermone Fidem docuere, paratos. BENCI, Quinque martyres, $5 \cdot 725^{-28}$

(The extraordinary honor was for them all; all were of the same mind, they all declared their joys in their happy expression when God revealed that the companions were prepared to confirm their faith, which they had shown in their speech, by the shedding of their blood.)

Book 6 opens with the reception of the martyrs in paradise.

Difficili adscensu. multi potuere vocati

Ferre gradum, paucis res obtigit, aequus amavit

Quos Pater, et miserans vultu respexit amico.

15 Agnovit Rodulphus iter, nam lacteus ibat

18 For a contemporary account, see John Correia-Afonso, S.J., ed., Letters from the Mughal Court: The First Jesuit Mission to Akbar, 1580-83, 2nd ed. (St. Louis: Institute of Jesuit Sources, 1981). 
Purpureo liquor immistus, procerumque piorum

Effigies memorem revocabat cognita mentem.

Quos inter cum se ipse nova sub imagine vidit

Et virtute pares socios, hoc munere laetus

20 Promissamque fidem superumque agnovit amorem.

Benci, Quinque martyres, 6.12-20.

(The ascent was difficult. Many have been summoned who had the power to mount the steps, but few manage; our father loved them equally, and pitying them looked back with a kindly expression. Rodolfo recognized the way, for a milky liquid mixed with red went on before, and he remembered the images of those pious lords. When he saw himself in a new form among their number and equal in virtue, overjoyed by his reward, he acknowledged the promised loyalty and the love shown by heaven.)

Two distinct classical motifs are here combined. At the beginning of Bellum civile, book 9, Lucan describes Pompey's (106-48 вCE) reception among the stars after his murder in Egypt:

But the spirit of Pompey did not linger down in Egypt among the embers, nor did that handful of ashes prison his mighty ghost. Soaring up from the burning-place, it left the charred limbs and unworthy pyre behind, and sought the dome of the Thunderer. Where our dark atmospherethe intervening space between earth and the moon's orbit-joins on to the starry spheres, there after death dwell heroes, whose fiery quality has fitted them, after guiltless lives, to endure the lower limit of ether, and has brought their souls from all parts to the eternal spheres: to those who are coffined in gold and buried with incense that realm is barred. When he had steeped himself in the true light of that region, and gazed at the planets and the fixed stars of heaven, he saw the thick darkness that veils our day, and smiled at the mockery done to his headless body. ${ }^{19}$

While the Stoics taught that the souls of the virtuous ascended to the bright ether beyond the moon's orbit, an alternate tradition imagined the Milky Way unfurling across the sky from the north to the south, as the "celestial palace" promised to the ancient heroes. ${ }^{20}$ Benci, however, was on dangerous ground theologically, as none of the martyrs had been officially recognized by the

19 Luc. 9.1-14; trans. J.D. Duff (Cambridge, MA: Harvard University Press, 1988), 505.

20 Manilius. Ast. 1.762-8o8. 
church, and neither Ignatius nor Xavier had yet been canonized. ${ }^{21}$ Acquaviva himself appears to the archbishop of Goa while he was celebrating an anniversary mass on the feast day of the Jesuit martyr Inácio de Azevedo (1527-70). ${ }^{22}$ Unlike the classical ghosts who return from Elysium, bloody and torn, Acquaviva is radiant with his wounds and, in a dense patchwork of Virgilian echoes, glows with his divinity:23

Pulchrius at multo diffundens corpore lumen

Affuit ante oculos, et nota maior imago.

Purpureo insignem iaciebat vertice flammam,

420 Aurea pendebant demissa monilia collo,

Corpus honos Tyrio redimibat regius ostro,

Et rutilo clarum lucebat sidere pectus.

BENCI, Quinque martyres, 6.417-22

(But a much more beautiful light pouring from his body appeared before his eyes, and an image greater than the one he knew. He was giving off a remarkable flame with a red tip, a golden collar hung down from his neck, royal honor redeemed his body with Tyrian purple and his chest was gleaming bright with a red star.)

The narrative continues with the recovery of the martyrs' bodies and their funeral. The numerous torches of the cortege turn night into day to unusual effect:

Ipsae etiam ueluti concusso stipite frondes

760 Defluere arboribus (Tristes cognomine dicunt)

Et uario flores nimbo consternere campos

Decidui, insolita decepti luce, diemque

21 Ignatius was beatified by Pope Paul v (r.1605-21) on July 27, 1609; Francis Xavier by the same pope on October 25, 1619; both were canonized by Pope Gregory XV (r.1621-23) on May 22, 1622; see Simon Ditchfield, "Coping with the beati moderni: Canonization in the Aftermath of the Council of Trent," in Ite inflammate omnia: Selected Historical Papers from the Conference Held at Loyola and Rome in 2006, ed. Thomas McCoog, S.J. (Rome: Institutum Historicum Societatis Iesu, 2010), 413-39.

22 July 15 (Julian calendar). Acquaviva was killed on the same day on which thirteen years before (1570) Inácio de Azevedo and his forty companions had been thrown overboard by the Huguenot skipper Sourie en route to the West Indies. Benci offers a dramatic description of their martyrdom at $6.235^{-94 .}$

23 His appearance recalls Ascanius (Aen. 7.278); while "Tyrio redimibat regius ostro" (6.421) combines "ut regius ostro" (Aen. 7.814) and "Tyrius conspectus in ostro" (Geo. 3.17). 
Ac Solem fulsisse rati: namque arbore flores

E Tristi gelidae recreantur noctis in umbra,

765 Nec perferre ualent radiati lumina Solis:

Nocturnis uiguere horis, cecidere diurnis.

BENCI, Quinque martyres, 6.759-66

(Yet this blossom itself, as though the tree trunk had been shaken, flutters down from the branches [they have named it "the Tree of Sorrows"] and the falling petals, deceived by the unaccustomed light, believing that it was day and the sun was shining, bestrew the plains in a colored cloud; for the flowers from "the Tree of Sorrows" bloom in the shade of the cold night but are unable to withstand the light of the shining sun; they thrive in the hours of the night and close during the day.)

In a remarkable piece of botanical observation, Benci is here referencing Indian Night-flowering Jasmin (Nyctanthes arbor-tristis) whose large white flowers open at dusk and fall at dawn. The pathetic fallacy of Mother Nature mourning the loss of the five companions is enhanced by a distinctly Jesuit interest in the nascent sciences.

The poem concludes with laments for the individual martyrs and closes with the inscription placed on the tomb as the five brothers are interred together: "until the final day will destroy the world and their commanded souls will return into their own bodies." 24

\section{The Heldenschau}

As we have seen, at the end of book 1 Acquaviva is transported into the heavens to witness a tableaux of early Christian martyrs, identified for him by his guardian angel. Whereas Anchises had indicated the great Romans who will follow on from Aeneas, the cortege here culminates in the present with the expectation of Acquaviva soon joining the march. Benci thus emphasizes the continuity of the Christian empire from its very beginnings to the present. ${ }^{25}$

\footnotetext{
24 Donec summa dies terrarum diruet orbem,

Et sua sese animae referent in corpora iussae.

BENCI, Quinque martyres, 6.944-45

25 See Simon Ditchfield, "What Was historia sacra? (Mostly Roman) Catholic Uses of the Christian Past after Trent," in Sacred History: Uses of the Christian Past in the Renaissance World, ed. Katherine van Liere, Simon Ditchfield, and Howard Louthan (Oxford: Oxford University Press, 2012), 72-97.
} 
Acquaviva is also seen to fulfil the prophecy of Saint Paul's words to the Corinthians: "For I think that God hath set forth us the apostles last, as it were appointed to death: for we are made a spectacle unto the world, and to angels and to men." ${ }^{26}$ In this context, the angel's frequent direct question, Aspicis? (Do you see? 1.351) is particularly striking. Echoing Anchises's words to Aeneas as future Roman heroes parade past on the Plains of Elysium, the question is not only directed at Acquaviva. It is also directed at the seminarian readership with the intention of inviting them to share Acquaviva's vision, meditate on their own vocation, and prepare for their work as professed members of the order. Benci references the recent cycle of paintings that had been added to the fifth-century circular church of Santo Stefano Rotondo on the Caelian hill:

240 Hunc spectat magis atque magis, secumque volutat Maxima quae impressa in gyrum spectacula pandit. Qualia, quae vivis hominum simulacra figuris, Qui Christum impavidi quondam cecidere professi Artifices pinxere manus, temploque sacrarunt

245 Roma tuo, Caeles ubi primum insedit Etruscus, Caelius e cuius deductus nomine collis;

Pannonii hic sedem Stephano posuistis et aram. BENCI, Quinque martyres, 1.240-47

(He looks at this more and more and ponders to himself what the wonderful sights depicted in the circle mean. Like the paintings with the living images of those people, who long ago acknowledged Christ and died fearlessly, which skillful hands have painted and dedicated in your church, Rome, where once Etruscan Caeles, from whom Caelian hill takes its name, had his abode; ${ }^{27}$ here the Hungarians have a house and have placed an altar to Saint Stephen.)

On the orders of Pope Gregory XIII Boncompagni (r.1572-85), the complex was given over to the Hungarians for use as a Jesuit seminary and in 1580 it was joined with the German College to become the Pontificum Collegium

$26 \quad$ Puto enim quod Deus nos apostolos novissimos ostendit tanquam morti destinatos, quia spectaculum facti sumus mundo et angelis et hominibus (1. Cor. 4:9).

27 Caeles Vibenna, see Cic. De off. 3.16.66; Rep. 2.18.33; Tac. Ann. 4.65: "The hill was originally called Oak Hill because of its dense growth of oak trees, and was later named 'Caelian' after Caeles Vibenna, an Etruscan chief who, for helping Rome, had been granted the hill as a residence by Tarquin Priscus." 
Germanicum et Hungaricum. Its walls were redecorated with a new fresco cycle by Niccolò Circignani, known as "il Pomarancio" (c.1530-97) (and later Antonio Tempesta [1555-1630]) of thirty-two scenes of early Christian martyrdom arranged chronologically according to the persecutions of the Roman emperors, beginning appropriately with an image of the Proto-martyr Stephen after whom the church is named. It has been convincingly argued that the format of frescoes is based upon the Evangelicae historiae imagines (1593), an illustrated book of Gospel meditations commissioned from the Jesuit Jerónimo Nadal (1507-80) by Ignatius himself. ${ }^{28}$ These frescoes, and the popular series of prints and engravings based upon them, were intended to provide the novices with material for meditation and prayer. Their central idea was not to depict martyrdom and death for their own sakes but as a means to salvation. Benci's ekphraseis of martyrdom in the Quinque martyres function in the same way, and were expected to be similarly engaging for the novice readership. ${ }^{29}$ The description of the recent execution of Edmund Campion is particularly striking:

Ecce illis aures ferro terebrantur acuto,

Perque ignem densa eiectant caligine fumum,

Striduntque incensae. uirgae illis terga, genasque

Concidere truces. Tum sacra in ueste sacerdos

$5^{20}$ Protrahitur, festisque urbem concursibus implet

Turpi impostus equo, manibus post terga reuinctis,

Ingenti clamore hominum, qui illudere capto

Certantes, rabidi in caelum conuicia iactant.

Hic abit, ex aede atque ipsis diuulsus ab aris.

525 Illum etiam saeuo resupinum in robore palmasque

Atque pedes tractum digitis nexuque rotarum,

Membrorum ut laxis corpus compagibus omne

Diffluat, et torto soluantur pectore crates,

Cernere erat. Iacuit nudo porrectus in antro

28 However, Ignatius did not live to see the work. The Evangelicae historiae imagines, adnotationes et meditationes was eventually printed at the press of Martin Nuntius in Antwerp in 1593 and 1594; see Thomas Buser, "Jerome Nadal and Early Jesuit Art in Rome," Art Bulletin $5^{8}$ (1976): 424-33; also Gauvin Alexander Bailey, Between Renaissance and Baroque: Jesuit Art in Rome, 1565-1610 (Toronto: Toronto University Press, 2003), 122-23, 132-52; illustrations $38-51$.

29 On ekphrasis, see Ruth Webb, Ekphrasis, Imagination and Persuasion in Ancient Rhetorical Theory and Practice (Farnham: Ashgate, 2009). 
530 Et capite, et tergo iuuenis, cui uincla retentant Et uexant sublime pedes: non ulla dolorum

Nec mora, nec requies; sunt, et qui corpora tardae Imposuere trahae, ut media raptentur in urbe Summum ad supplicium, uerrentes uertice terram.

535 Nec procul infelix arbor, sed morte beatos

Felici factura uiros, gladiique cruenti

Visuntur, iuxtaque ignes: nec defit aquae uis

Flammifera, aerato, uulsas e corpore fibras

Exceptura lacu: longis hastilibus horrent

540 Praefixa hinc capita: et suspensi compita circum

Informes artus: et membra fluentia tabo.

BENCI, Quinque martyres, 1.516-41

(Look, their ears are sliced off with a sharp knife, and, burnt on a fire, they give out a thick cloud of smoke and hiss and crackle. Cruel rods have lacerated their backs and legs. Then the priest dressed in his sacred vestments is dragged out, and sat upon an old nag with his hands bound behind his back, he fills the city with a holiday crowd; the enraged mob, vying with each other to mock the prisoner, hurl abuse into the sky with a great clamor. He goes away, wrenched from the church and from the altars themselves. That renowned man could be seen lying spread-eagled upon his back on a savage wooden frame with his hands and feet tied to winches so that, with loosened joints, his whole body may be pulled in different directions and his limbs disengaged from his racked torso. Stretched out, the young man lay in a hollow with a bare head and back with chains binding him fast and his feet shaking in the air. There is no pause or respite from the pain. Those men are here who have placed the bodies upon slow-moving hurdles so that they may be drawn violently into the city center for execution, sweeping the ground with their heads. The miserable gallows is not far off, which will make these men blessed in a happy death; and the bloody knives are seen, and the fires standing nearby; the water, which will receive their entrails torn from their bodies, is boiling furiously in a bronze cauldron. Thence their heads, stuck on tall pikes, shudder; and their shapeless limbs, suspended at the cross-roads, and their privy parts flowing with gore.)

Leaving aside, as much as one can, the brutality of the punishment meted out to Campion and his companions, the inclusion of these horrific scenes can be explained as a rhetorical demonstratio where "an event is so described in words 
that the business seems to be enacted and the subject to pass before our eyes." ${ }^{30}$ Here the repeated appeal to sight, ecce (l.516), cernere erat (l.529), visuntur (l.536), and the present tense of the first three lines makes the scene particularly powerful, while the senses of touch (terebrantur, 1.516) and hearing (stridunt, l.518) are also elicited, turning Benci's readers into engaged spectators. Indeed, these specific details, cataloged impressionistically, combine in the imagination to create vivid tableaux that are greater than the sum of the parts. ${ }^{31}$ In his lectures on poetry, Benci had argued that this imaginative involvement should be the norm of the educated student. While discoursing on a simile from Vergil's Georgics (Ut saepe ingenti bello, 4.279-83) in his eighth oration ("In Praise of Poetry"), Benci concludes: "Who, when they read such lines, is so completely stupid or deaf, that he does not seem to be in that very battle, in the midst of the heat of the fighting and bloodshed?"32 More importantly, this rhetorical "demonstration" coincides with specific Jesuit meditation practices as expounded in the Spiritual Exercises, where applicatio sensuum involves vision, hearing, and touch. Thus Benci's audience not only knew what happened but through his vivid ekphraseis felt as if they were eyewitnesses sharing the experience imaginatively and emotionally.

It should also be recalled that epic tradition going back to Homer had sanctioned descriptions of the hero's mutilation after death (for example, the multiple wounding of Hector's corpse, Il. 22.369-750). Silver Latin epic is equally replete with explicit scenes of torture and dismemberment which, in turn, affected accounts of the passion of the early martyrs by Christian writers (compare, for example, Prudentius, "On the Crowns of the Martyrs," Peristephanon, 11). As the historian Stanley F. Bonner has shown, rhetorical exercises of this kind were a favorite subject of the declamation schools in imperial Rome. ${ }^{33} \mathrm{He}$ observes that "audiences long inured to the butchery of the gladiatorial shows in real life readily gloated over still more lurid details provided by over-imaginative declaimers," and compares Lucan's long account

30 [Cicero], Rhet. ad Her. 4.55.68; trans. Harry Caplan (Cambridge, MA: Harvard University Press, reprint. 1981), 405 .

The effect is described by Quintilian, who admitted that when reading certain vivid passages in Cicero the image that arose in his mind contained details that were not in the text (Inst. 8.3.65).

Quis enim est usque adeo tardus et surdus, quin ea cum legit, esse sibi in eo proelio, in medioque ardore pugnae caedisque videatur? Francesco Benci, Oratio octava, eiusdem argumenti (Duae: Johannes Bogardus, 1597), 5ov. Here, Benci echoes the precepts outlined by Vida in De arte poetica, 2.367-94 and defined earlier by Quintilian (Inst. 6.2.32). Stanley F. Bonner, "Lucan and the Declamation Schools," in Lucan: Oxford Readings in the Classics, ed. Charles Tesoriero (Oxford: Oxford University Press, 2010), 69-106. 
of the Sullan proscriptions (Bellum civile, 2.134-232) with the manner in which declaimers describe the sufferings inflicted on beggar-children: "this [child] has had the joints of his feet torn and his ankles wrenched, this one has had his legs crushed; he smashed that one's thighs without harming his feet and legs; raging in a different way against each that bone-breaker cuts off the arms of one, slices the sinews of another; one he twists, another he castrates; the shoulder blades of one he beats into an unsightly hump and so tries to get a laugh from his cruelty." ${ }^{34}$ Benci would have had first-hand knowledge of these texts, not only in his official capacity as professor of rhetoric at the Collegium Romanum but because he had also completed and supervised the publication of Muret's edition of Seneca's philosophical and rhetorical works after Muret's death. ${ }^{35}$

This passage also suggests a triptych narrating Campion's arrest and journey to London (ll.519-24); torture in the Tower (ll.525-32); and execution at Tyburn (ll.532-41). ${ }^{36}$ Circignani also decorated the walls of the medieval church of the English College with scenes of mission and martyrdom (c.1582-83). Although the original series is now lost, a complete set of engravings was immediately published under the title Ecclesiae Anglicanae trophaea (1584). Three scenes are similarly devoted to Campion's torture, journey to Tyburn, and dismemberment, and thus suggest a further link between Benci's poem and Circignani's fresco cycles.

Moreover, these extended descriptions of the martyrs' sufferings counter the damnatio memoriae of their execution and act as funeral orations which magnify their acts of bravery in terms of classical heroism. Polybius (c.200-c.118),

34 "Huic convulsi pedum articuli sunt et extorti tali, huic elisa crura; illius inviolatis pedibus cruribus femina contudit; aliter in quemque saeviens ossifragus iste alterius bracchia amputat, alterius enervat, alium distorquet, alium delumbat; alterius diminitas scapulas in deforme tuber extundit et risum in crudelitate captat" (Sen. Contr., 10.4.2); cited in ibid., 94 .

35 L. Annaeus Seneca a M. Antonio Mureto correctus et notis illustratus (Rome: Bartholomeus Grassius, 1585). The rhetorician Lucius Annaeus Seneca "the elder" (c.55 BCE-c.37 CE) and his son, the philosopher and playwright Lucius Annaeus Seneca "the younger" (c.4 BCE-65 CE), had not yet been distinguished.

36 Note also the contemporary publication of Cesare Baronio's Oratorian colleague: Antonio Gallonio, Trattato degli instrumenti di martirio, e delle varie maniere di martoriare usate da gentili contro christiani (Rome: Ascanio e Girolamo Donangeli, 1591) with forty-seven engravings by Antonio Tempesta; later republished in Latin with cruder woodcuts (1594); see Jetze Touber, Law, Medicine and Engineering in the Cult of Saints in Counter-Reformation Rome: The Hagiographical Works of Antonio Gallonio (1556-1605) (Leiden: Brill, 2014), 101-54. 
it will be recalled, had claimed that the most important consequence of the funeral oration was to inspire young Roman spectators "to endure every suffering for the public welfare in the hope of winning the glory that attends upon brave men."37 Benci's account of each martyr's death in book 5 acts in a similar way. The protracted description of the torture of Pietro Berno, who appears to have suffered a double martyrdom at the hands of the enraged mob, punctuated by Berno's dialogue with his tormentors, is supplemented by frequent authorial asides which direct the readers' response to the account being read (or heard) and the vivid image it has evoked:

Ille autem caelum intendens uix uulnera sentit Plurima, letiferos animo superante dolores. "O Pater omnipotens, quas possum dicere grates

1130 Pro Nato qui posse tuo me hoc ducere letum Dignatus, tales uoluisti corpore poenas Posse pati laetanti animo? Pater, adde dolorem: Adde etiam patientem animum, Fideique tenacem. Argue nec sceleris populum, quem decipit error."

1135 Vix ea. Cum iuuenis crocea uelatus ab alto Veste uenit, sertumque uirens insignia palmae Nobilis ostentans. "O caeli aucture triumphus Miles," ait, "persta, et summis ne defice rebus. Victori datur aeterna cum laude corona." BENCI, Quinque martyres, 5.1127-39

(Yet that renowned man [Berno], concentrating upon heaven, scarcely feels his multiple wounds as his soul defeats the death-bringing suffering. "Omnipotent Father, what thanks can I give to your Son, who considered me worthy to endure this death, and because you wished that such torments could be endured by my body while my mind rejoices? Father, increase the pain; even prolong the suffering soul, and its tenacity to faith. Do not condemn the crime of the people whom error has deceived." He had scarcely finished uttering these words, when a youth, veiled in a golden cloak, descended from on high, displaying the badges of noble palm and a green garland. He said, "Stand firm soldier, who will increase heaven's triumph, do not be found wanting in these last moments. The crown is awarded to the victor with eternal glory.") 2011), 3:390-91. 


\section{Conclusion}

As we have seen, this first Jesuit epic was programmatic. It was written in response to contemporary (confessional) circumstances, with a specific purpose and for a select audience. It was composed primarily for the edification of students who would perhaps face similar situations in Jesuit global missions. The graphic scenes of martyrdom provide an exemplary model of resolve and determination by making the audience feel present and emotionally engaged, for these ekphraseis were intended to transport the audience directly to the scene where they would not merely see the event but feel it as well.

Two epigrams on martyrdom reveal that Benci also thought of these acts of sacrifice in emblematic terms:

De martyribus emblemata duo

Silex ferro percussa.

Icta silex differ scintillas, et iacit ignem: ${ }^{38}$

Si non icta foret, frigida et atra foret.

Dia fides vexata odiis, iactata periclis,

Quae latuere pio pectore prodit opes.

Tus incensum.

Tus honor est superis, odor est mortalibus, ut se

Leniter in ventos explicuisse potest.

Irrita sed spes fit tenues evadere in auras,

Flamma nisi in nubem soluit odoriferam.

Casta fides terris grata est, gratissima caelo:

Hoc animos, illae fortia facta vident.

Nec memoranda aeque, quam cum pietatis amore

Splendet in accensis inviolata rogis:

Laetus et in mediis martyr canit ignibus, "Uror,

Uror, ut hoc Christi fragret odore domus."

(Two emblems about martyrs.

Flint struck by Iron.

38 A classical commonplace; but cf. ut silicis venis abstrusum excuderet ignem, Verg. Geo. 1.135 . 
Flint when it is struck emits sparks and casts out a fire. If it were not struck it would be cold and dull. Divine faith injured by hatred and cast about by dangers projects the resources that have lain hidden in a pious heart.

Burning Frankincense.

Incense is an honorary gift for those who dwell in heaven, its perfume is a reward for mortals, as it is gently diffused into the air. But hope has no effect, evaporating in a light breeze, unless a flame has dissolved it into a perfumed cloud. Chaste faith is pleasing on earth, most pleasing in heaven: mortals witness the brave deeds, heaven sees the courageous souls. Inviolable faith which shines bright at the stake with the love of piety must not be commemorated in the same way. The happy martyr sings in the midst of the flames, "I burn, I am burning so that Christ's house may be sweet with this perfume." $)^{39}$

As Kristof van Assche has observed: "Ignatius Loyola himself created in the Spiritual Exercises (1548) an image-language, strictly coded in order to lead the associative powers of the image in desired, controlled directions." ${ }^{40}$ Benci's new epic, replete with sensory ekphraseis of martyrdom, was conceived in the same spirit. As part of the propaganda battle with the Protestants over the significance of saints, martyrs, and their relics, the descriptions in this new type of epic were intended to replace the terrestrial glory promised to ancient heroes with the eternal glory of entry into paradise. Like a modern paperback, the first editions were printed in a pocket-sized format between soft vellum covers to enable these books to be taken and read everywhere as the author had wished, thus ensuring that "these events would not lie hidden in the shadows of a long night." 41

39 Francesco Benci, Carminum libri quattuor (Ingolstadt: David Sartorius, 1592), 181. Note that in the second poem the language of Latin erotic elegy (Uror, "I burn with passion") is recast in a Christian context to emphasize the martyrs' chaste passion.

40 Kristof van Assche, "Louis Richeome, Ignatius and Philostratus in the Novice's Garden: Or, the Signification of Everyday Environment," in The Jesuits and the Emblem Tradition, ed. John Manning and Marc van Vaeck (Turnhout: Brepols, 1996), 3-10; 4.

41 Rodolfo Acquaviva was beatified in 1893. In Jesuit churches, the post-communion prayer on July 27 is as follows: "Grant, O Lord Jesus Christ, that we who have been strengthened by participation in this salutary sacrifice may imitate the unconquered constancy in faith and charity of Thy blessed Martyr Rudolf and his companions." Cited by Edward Maclagan, The Jesuits and the Great Mogul (London: Vintage, 1960; first published 1932), 40. 